\title{
Criteria for assessing the level of physical fitness and physical state of football players with cerebral paralysis, taking into account their sports classes
}

Serhii Ovcharenko ${ }^{\mathrm{ABCDE}}$, Artem Yakovenko ${ }^{\mathrm{ABCDE}}$, Tetiana Sydorchuk ${ }^{\mathrm{ACDE}}$, Iryna Stepanova ${ }^{\mathrm{ACDE}}$, Oleksandr Pikiner ${ }^{\mathrm{ACDE}}$ Prydniprovsk State Academy of Physical Culture and Sport, Ukraine

Authors' Contribution: A - Study design; B - Data collection; C - Statistical analysis; D - Manuscript Preparation; E - Funds Collection

\section{Abstract}

Purpose:

The article is devoted to finding ways to optimize the training of players with cerebral palsy (CP). It is determined that testing and elaboration of criteria for assessing the level of physical fitness of football players with cerebral palsy can be used as a mean of evaluation the sportsmanship of football players of this nosology in training and competitive activities. The purpose of the study is to determine the level of physical and functional preparedness of football players with cerebral paralysis and to develop criteria for their evaluation during the intensive training period, taking into account the functional classes of athletes.

Material: $\quad 25$ football players with cerebral palsy, candidates and members of the national team of Ukraine, threetime Paralympic champions, multiple world and European champions took part in the study voluntarily. Athletes of the selected group have 5-8 classes of the adapted classification of the International Association of Cerebral Palsy (CP-ISRA) for CP-Football. Biochemical parameters were studied before and after training work of different focus. The value of maximum oxygen consumption (MOC) was determined by means of bicycle ergometric testing. The physical state and level of physical fitness of football players were monitored during the study. The research was conducted on the basis of the research laboratory of Prydniprovsk State Academy of Physical Culture and Sport and on the basis of the Municipal Institution "Dnipropetrovsk Medical and Physical Dispensary" of the Dnipropetrovsk Regional Council.

Results: $\quad$ It was found that athletes with cerebral paralysis are able to adequately tolerate heavy physical loads. Football players with disabilities had biochemical parameters of blood sampling and registration of recovery processes of the cardiovascular system after training activities of different focus within the permissible norm for both healthy athletes. Obtaining such data became the basis for the intensification of training process, which promoted the development of motor skills of football players.

Conclusions: $\quad$ Obtained data were the basis for creation the criteria for assessing the level of physical fitness of football players depending on their sports classes. In future, this will allow coaches to determine the effectiveness of the training period, obtain information about the condition of players in training, in the recovery process. On this basis it will help to individualize the workload of players and adjust the training process. The analysis of a direction of preparation and decision-making about educational process correction for football players with disabilities can be realized according to the received data in various structural formations of an annual macrocycle.

Keywords: cerebral palsy, physical fitness, testing, international classification, sports classes.

\section{Introduction}

Sports movement of people with disabilities is a part of the modern Olympic movement. This creates a powerful stimulus to mobilize the body's reserve capacity and gives hope to people with severe disabilities to overcome their diseases $[1,2]$. This approach takes place in fundamental sources and research of specialists [35]. Ensuring the activities of Ukrainian national teams of athletes with disabilities, their training and participation in international competitions is one of the priorities of the Ministry of Youth and Sports of Ukraine and Ukrainian center "Invasport" [6]. Athletes with disabilities in Ukraine include 4 nosologies [7, 8]: with cerebral palsy (CP), with mental and physical disabilities, with vision impairments, with hearing impairments. Football for people with cerebral palsy is played by athletes with (c) Serhii Ovcharenko, Artem Yakovenko, Tetiana Sydorchuk,

Iryna Stepanova, Oleksandr Pikiner, 2021

doi:10.15561/26649837.2021.0207 minimal criteria for ataxia, hypertension or athetosis (i.e., three types of disease that are most often associated with people with neurological disorders). Athletes with motor control disorders (brain injuries) have recently been allowed to compete in this sport $[9,10]$. Scientists have proven that it can be the result of cerebral paralysis, apoplexy or traumatic injury. This impairs the function of the lower limbs and limits the performance of specific skills, for instance, jumping, running, changing directions or dribbling skills [11 - 13].

The International Paralympic Committee (IPC) applies a functional system to all athletes participating in official events. It includes eight functional classes: the first four groups (grades 1-4) correspond to athletes who need a wheelchair to engage in any sport. The last four groups (grades $5-8$ ) correspond to athletes who do not need a wheelchair. The classification developed by the International Federation of Cerebral Palsy Football 
(IFCPF) was used for CP football. It is defined as the grouping of players into sports classes according to the extent to which their defects affect their motor activity $(10,14)$. Classification groups assign classes to athletes by collectively reviewing the results of functional and motor tests, which are constantly modified and improved [1518]. After the 2016 Paralympic Games, the classification of football CP has undergone very significant changes [9]. Reina et al. [18] have developed four classes (FT) for CPfootball:

1) Class FT5 includes impairments of two legs, impairments of both legs and arms, meanwhile the lower limbs are more impaired than the upper ones; or athletes with dystonia, whose lower limbs are more impaired than the upper ones.

2) Class FT6 includes moderate impairments of all four limbs. Athetosis, dystonia, or ataxia are usually the most common factors.

3) Class FT7 includes the degree of spasticity of body half. Athletes walk, run with a clearly visible limping due to spasticity in the lower limb.

4) Class FT8 includes hemiplegia, monoplegia in the lower limbs; athetosis, dystonia, ataxia, mixed cerebral palsy or other neurological conditions.

Scientists have discovered relations between impairments and limitations of motor activity in this sport [19]. Studies by Anastasiadis et al. [20] showed that players with CP have the basic elements of movement technique, as in classic football, which requires players to use strength, speed, agility, flexibility and endurance. Davids [21] determined that CP-football is characterized by intermittent motor actions of short duration and high intensity. Bangsbo [22] investigated the motor activity of players during a football match. Ovcharenko et al. [23] found that the most backward part in the structure of physical fitness of most football players with cerebral palsy is speed and strength preparedness, which is associated with the peculiarities of the disease. Person with hemiparesis (form of cerebral paralysis) couldn't do symmetrical movements; jumps and jumps off require compensatory movements of the healthy half of the body. In this regard, the development of jumping in players with lesions of one or both legs are a long and continuous process. As soon as the level of motor activity decreases, and this usually happens in the transition period, muscle atrophy occurs. This significantly negatively affects the speed and strength capabilities of athletes [23].

Considering the complex structure of sports training in team games, experts offer a comprehensive approach to assessing the preparedness of athletes [24, 25]. Reina et al. have developed tests used in the classification of players with CP [26]. Meanwhile, there are serious problems with the interpretation of the data obtained during the classification and their use in the training of athletes with disabilities. The reasons are the lack of criteria to assess the level of physical state and physical fitness of players of this nosology during the long training process and, based on this, the inability to compare the initial state of the athlete, his condition against training loads and the required target condition.

The hypothesis of the study is to scientifically predict the possibility of controlling the level of physical fitness of football players with cerebral palsy to improve the quality of their long-term sports training.

The purpose of the study is to determine the level of physical and functional preparedness of football players with $\mathrm{CP}$ and to develop criteria for their evaluation during the intensive training period, taking into account the functional classes of athletes.

\section{Material and methods}

Participants: 25 football players with cerebral palsy, candidates and members of the national team of Ukraine aged 20 to 34 took part in the study voluntarily. Athletes of the selected group have 5-8 classes of the adapted classification of the International Association of Cerebral Palsy (CP-ISRA) for CP-Football. All athletes gave informed consent to participate in the research.

Procedure: Anthropometric researches on the basic rules and principles connected with selection of means of measuring equipment and methods of measurement were carried out [27]. The following anthropometric parameters were measured: body length, body weight, chest circumference (CC), vital capacity of the lungs (VLC). Bicycle ergometric testing was used to determine the value of maximum oxygen consumption (MOC). During the dispensary examination after warming up (3-4 minutes) and rest, the athletes performed a single physical activity for 5 minutes. Pedaling speed -60 rotations per minute. The load power increases to the range of heart rate $-120-170$ heartbeats per minute. After cycling ergometric testing, the values of MOC were determined using a special nomogram [28].

The biochemical method allows determining some biochemical indicators of athletes' condition: the state of training, the state of overtraining, recovery, etc. Strength load on the trainers included exercises for developing maximum leg muscle strength using weights $70 \%$ or more of the maximum with full range of motion. It was measured the amount of creatinine, creatine and lactic acid in blood, creatinine and creatine in urine, urea in blood serum before and after strength load performed by players on the trainers.

A running test (cross-country running 9000 meters with an average speed of 3.5-4.0 meters per second) was used in aerobic mode. The power of work is such that the energy supply of the working muscles can occur (mainly or exclusively) due to aerobic processes associated with sufficient oxygen consumption. Therefore, the power in these exercises can be estimated by the level (speed) of remote oxygen consumption [29]. It was measured the concentration of non-esterified fatty acids (NEFA) and urea in blood serum, lactic and pyruvic acid, glucose and hemoglobin in blood taken from athletes before and after running. Heart rate and blood pressure (BP) were measured to assess post-cross recovery processes. Measurement of blood pressure allows identifying the dynamics of indicators that well reflect the body's preparedness 
for exercise [30]. Heart rate and blood pressure were registered at rest, immediately after exercise and during recovery.

To diagnose the level of players' special physical training, a minimized set of informational and reliable pedagogical tests was used. It included an assessment of the starting speed for the running time of 10 meters from the spot. Distance speed was measured by the running time of 50 meters from the spot. Speed and strength abilities were registered by the height of jump up from the place with using of a contact platform and an electronic stopwatch. Special endurance was determined according to the integrated time of shuttle run $7 \times 50$ meters. The informativeness and reliability of these tests have been proven by previous studies [31,32].

Statistical analysis. Data were processed by descriptive and comparative statistical procedures. Mathematical statistics were conducted by the method of calculating quantitative indicators. We calculated the arithmetic mean (x), standard deviation (S). The reliability of the obtained data was determined by Student's t-test and was considered statistically significant at $\mathrm{p}<0.05$ and $\mathrm{p}$ $<0.001$.

\section{Results}

Studies of biochemical parameters of football players with disabilities before and after training load with different focus provide an opportunity to find out how training loads affect the physical condition of football players. Running and strength work were offered to football players with cerebral palsy as control exercises. An average speed of football players was $3.5-4 \mathrm{~m} \cdot \mathrm{s}^{-1}$ during the running. Strength load on the trainers included exercises for developing maximum leg muscle strength using weights $70 \%$ or more of the maximum with full range of motion. Obtained results show that biochemical parameters of athletes before and after exercise were within the allowable norm for healthy athletes (Table 1).

Test subjects adequately tolerated to proposed large physical load: rapidity of recovery (according to heart rate registration) after running was also quite fast (Table 2). I.e. we can confirm that proposed load corresponded to

Table 1. Biochemical parameters of football players with CP before and after training load of different focus $(n=25)$

\begin{tabular}{|c|c|c|c|c|c|c|c|}
\hline \multirow{2}{*}{ Focus of training } & \multirow{2}{*}{ Indicators } & \multicolumn{2}{|c|}{ Before load } & \multicolumn{2}{|c|}{ After load } & \multirow[b]{2}{*}{$\mathbf{t}$} & \multirow[b]{2}{*}{$\mathbf{p}$} \\
\hline & & $\overline{\mathbf{x}}$ & $\mathbf{S}$ & $\overline{\mathbf{x}}$ & $\mathbf{S}$ & & \\
\hline \multirow{6}{*}{ 1. Strength load } & Creatinine in blood, $\mathrm{mkmol} \cdot \mathrm{I}^{-1}$ & 101.9 & 1.64 & 102.8 & 2.03 & 1.71 & .093 \\
\hline & Creatine in blood, $\mathrm{mmol} \cdot \mathrm{I}^{-1}$ & 186.9 & 10.4 & 292.1 & 14.0 & 30.16 & $.000 *$ \\
\hline & Creatinine in urine, $\mathrm{mmol} \cdot \mathrm{I}^{-1}$ & 35.2 & 1.9 & 32.3 & 2.3 & 4.86 & $.000^{*}$ \\
\hline & Creatine in urine, $\mathrm{mmol} \cdot \mathrm{I}^{-1}$ & 6.4 & 1.0 & 10.6 & 1.5 & 11.66 & $.000^{*}$ \\
\hline & Urea, $\mathrm{mmol} \cdot \mathrm{I}^{-1}$ & 6.8 & 0.3 & 7.1 & 0.2 & 4.16 & $.000 *$ \\
\hline & Lactic acid, $\mathrm{mmol} \cdot \mathrm{I}^{-1}$ & 2.0 & 0.1 & 4.5 & 0.2 & 56.81 & $.000^{*}$ \\
\hline \multirow{4}{*}{$\begin{array}{l}\text { 2. Cross-country running } \\
9000 \mathrm{~m}\end{array}$} & Hemoglobin, $\left.\mathrm{g} \cdot\right|^{-1}$ & 149.4 & 1.71 & 163.2 & 1.32 & 32.09 & $.000^{*}$ \\
\hline & NEFA, m-equivalent $\left.\cdot\right|^{-1}$ & 0.59 & 0.01 & 0.61 & 0.02 & 5.0 & $.000 *$ \\
\hline & Urea, $\mathrm{mmol} \cdot \mathrm{l}^{-1}$ & 7.52 & 0.34 & 8.75 & 0.41 & 12.05 & $.000^{*}$ \\
\hline & Lactic acid, $\mathrm{mmol} \cdot \mathrm{I}^{-1}$ & 1.99 & 0.12 & 5.07 & 0.21 & 70.0 & $.000^{*}$ \\
\hline
\end{tabular}

$* p<0.001$

Table 2. Physiological parameters of football players with CP before and after cross-country running $(n=25)$

\begin{tabular}{|c|c|c|c|c|c|c|c|c|c|}
\hline \multirow[t]{2}{*}{ Indicators } & \multicolumn{2}{|c|}{ Before load } & \multicolumn{2}{|c|}{ After load } & \multicolumn{2}{|c|}{$\begin{array}{l}\text { Recovery after } \\
5 \mathrm{~min} .\end{array}$} & \multicolumn{2}{|c|}{$\begin{array}{l}\text { Recovery after } \\
10 \mathrm{~min} .\end{array}$} & \multirow[t]{2}{*}{$\begin{array}{l}\% \text { increase / } p \text { (before } \\
\text { running and 10-minutes } \\
\text { recovery) }\end{array}$} \\
\hline & $\overline{\mathbf{x}}$ & $S$ & $\overline{\mathbf{x}}$ & $S$ & $\overline{\mathbf{x}}$ & $S$ & $\overline{\mathbf{x}}$ & $S$ & \\
\hline $\begin{array}{l}\text { Heart rate, beats per } \\
\text { min. }\end{array}$ & 74.0 & 2.7 & 152.8 & 5.6 & 96.0 & 2.5 & 79.9 & 3.4 & \\
\hline$\%$ increase & & & +69.48 & & -45.65 & & -18.30 & & +7.66 \\
\hline$p$ & & & $.000 *$ & & $.000 *$ & & $.000 *$ & & $.000 *$ \\
\hline $\begin{array}{l}\text { Systolic blood } \\
\text { pressure, } \mathrm{mmHg}\end{array}$ & 117.5 & 1.4 & 135.9 & 3.8 & 119.1 & 2.7 & 112.0 & 2.1 & \\
\hline$\%$ increase & & & +14.52 & & -13.17 & & -6.14 & & -4.79 \\
\hline$p$ & & & $.000 *$ & & $.000 *$ & & $.000 *$ & & $.000 *$ \\
\hline $\begin{array}{l}\text { Diastolic blood } \\
\text { pressure, } \mathrm{mmHg}\end{array}$ & 73.0 & 1.5 & 79.0 & 2.4 & 77.3 & 1.9 & 75.0 & 1.8 & \\
\hline$\%$ increase & & & +7.89 & & -2.17 & & -3.02 & & +2.7 \\
\hline$p$ & & & $.000 *$ & & $.007^{* *}$ & & $.000 *$ & & $.000 *$ \\
\hline
\end{tabular}


the functional capabilities of athletes with cerebral palsy. The positive dynamics of the concentration of lactic acid and urea, the decrease of NEFA after exercise indicate a high level of functional preparedness of football players at the time of diagnosis. The cardiovascular system of football players responded with a combined increase of heart rate, increased systolic blood pressure and pulse pressure. It indicates that athletes' level of preparedness match to performed load.

To assess the impact of the level of players ' physical fitness on their game activity, a correlation analysis was calculated between the level of motor skills development and technical and tactical actions during games (Table $3)$. The nature of the statistical relationship between the volume of technical and tactical actions and special endurance deserves attention. If we take into account the fact that according to the rules of football CP field's size is $55 \times 75$ meters without fixing the position "out" and each team involves only 7 players, the leading quality in the structure of physical fitness of football players, in our opinion, is special endurance. This assumption was confirmed by the results of correlation analysis.
The increase of special endurance is associated with the number of short and medium passes in games $(r=-0.81$, $\mathrm{p}<0.05)$, long passes $(\mathrm{r}=-0.77, \mathrm{p}<0.05)$, dribbling $(\mathrm{r}=$ $0.82, \mathrm{p}<0.05)$, head play $(\mathrm{r}=-0.71, \mathrm{p}<0.05)$, shots on goal $(\mathrm{r}=-0.80, \mathrm{p}<0.05)$.

According to the study design we significantly increased the means of anaerobic (lactate and glycolytic) orientation, rationally combined the loads withs different focus at the stages of the annual cycle. This contributed to the development of motor skills (especially speed and strength qualities and special endurance) [33].

Based on the data obtained during the control and analysis of indicators, we developed criteria for assessing the preparedness of football players with cerebral palsy, taking into account the motor abilities of athletes (their sports classes) (Table 4).

The presented criteria have three levels. The first level determines the lower limit of physical fitness indicators and physical development of football players with cerebral palsy, who have the highest degree of musculoskeletal disorders (classes FT5 and FT6 of international classification). The second level corresponds

Table 3. Correlation matrix of the relationship of physical fitness of football players with CP and their technical and tactical actions in competitions

\begin{tabular}{|c|c|c|c|c|c|}
\hline Indicators & $\begin{array}{l}\text { Run } 12 \\
\text { min. }\end{array}$ & Run $10 \mathrm{~m}$ & Run 50 m & Jump up & $\begin{array}{l}\text { Shuttle run } \\
7 \times 50 \mathrm{~m}\end{array}$ \\
\hline Short and medium passes & -.18 & -.01 & .02 & .35 & $-.81 *$ \\
\hline Long passes & .07 & $-.90 *$ & -.33 & $.69 *$ & $-.77^{*}$ \\
\hline Dribbling & .19 & .33 & -.24 & -.20 & $-.82 *$ \\
\hline Interseption & -.24 & -.41 & .15 & $.75^{*}$ & .51 \\
\hline Bypass & -.18 & -.11 & -.05 & $.72 *$ & .01 \\
\hline Ball tackle & -.16 & .01 & .14 & -.40 & .61 \\
\hline Head play & -.09 & .04 & -.14 & .12 & $-.71 *$ \\
\hline Shots on goal & -.01 & .30 & -.13 & .01 & $-.80 *$ \\
\hline $\begin{array}{l}\text { Total amount of technical and } \\
\text { tactical actions }\end{array}$ & .01 & .03 & -.01 & -.08 & $-.49 *$ \\
\hline
\end{tabular}

$* \mathrm{p}<0.05$.

Table 4. Criteria for assessing the morphofunctional condition and physical preparedness of football players with $\mathrm{CP}$, taking into account the degree of musculoskeletal system impairments (their sports classes)

\begin{tabular}{llll}
\hline Indicators & $\begin{array}{l}\text { Functional class FT5, FT6 } \\
\text { (level 1) }\end{array}$ & $\begin{array}{l}\text { Functional class FT7 } \\
\text { (level 2) }\end{array}$ & $\begin{array}{l}\text { Functional class FT8 } \\
\text { (level 3) }\end{array}$ \\
\hline Body mass, kg & 66.6 & 69.5 & 72.4 \\
Body length, cm & 174.6 & 176.7 & 178.7 \\
CC, cm & 91.6 & 93.8 & 96.1 \\
VLC, ml & 4222 & 4525 & 4828 \\
MOC, ml-min·kg-1 & 44.9 & 48.8 & 52.6 \\
Run 12 min., m & 2600 & 2800 & 3000 \\
Run $10 \mathrm{~m}, \mathrm{sec}$. & 1.88 & 1.85 & 1.80 \\
Run $50 \mathrm{~m}, \mathrm{sec}$ & 6.80 & 6.60 & 6.50 \\
Jump up, cm & 42.4 & 45.7 & 47.9 \\
Shuttle run $7 \times 50 \mathrm{~m}, \mathrm{sec}$. & 70.6 & 66.6 & 60.7 \\
\hline
\end{tabular}


to the indicators of footballers with an average degree of musculoskeletal system impairment (class FT7 of international classification). The third level shows physical state of football players with the lowest degree of musculoskeletal disorders (according to class FT8 of international sports classification).

Achieving such results allows coaches to select for the national team, as well as to determine the effectiveness of the training process at the stages of the annual training cycle and, in particular, at the stage of preparation for international competitions.

\section{Discussion}

The analysis of literature sources on the problem of training football players allowed to establish the importance of the control system during the training process. The obtained results of complex control should be used for planning and correction of training plans. The content of programs and plans depends on their authenticity, reliability and informativeness, and the coach receives objective information about the health and mental state of each player, the impact of physical activity and changes in the functional systems of the body. A lot of experimental material has been accumulated on the problems of long-term training and control in football $[24,25]$. The authors of these studies thoroughly and in detail considered the issue of pedagogical control of football players' training both in the process of longterm training and in various structural formations of the annual training cycle. Many studies have been aimed to improve the training process of athletes with disabilities in team [34-36] and individual sports [37-39]. We have developed a program of the training process in the annual cycle for football players with CP [33]. The advantage of our research is the possibility of applying a control system for football players with cerebral palsy. A comparative analysis of the test results of the control and experimental groups, which were trained in different programs and methods, showed the effectiveness of the proposed program. The implementation of this program contributed to the realization of the individual capabilities of the athletes of the experimental groups. Analysis of the results of retesting the level of physical fitness revealed that football players with $\mathrm{CP}$ of the experimental group compared to the previous testing had a significant ( $\mathrm{p}$ $<0.05)$ increase in all indicators. Athletes of the control group had significant improvement $(p<0.05)$ only in indicators of speed.

Athletes with cerebral paralysis can adequately tolerate heavy training loads. Results obtained for the first time in the testing process indicate that the medical and biological indicators of football players with $\mathrm{CP}$ before and after exercise were within the permissible norm for healthy athletes. In previous studies, we found certain patterns of influence of physical fitness on the playing activity of football players. A correlation analysis was conducted between the average indicators of the level of motor skills development and technical and tactical actions during official international competitions. This allowed to determine that the leading quality in the structure of physical fitness of players with $\mathrm{CP}$ is special endurance. Thus, the higher level of special endurance in players with $\mathrm{CP}$, the greater amount of load they can perform on the field during the game [40]. The results of our studies were supplemented by data from Yanci and co-authors [41] to determine the external load that players perform during games. We supplemented the data of Lukovska with coauthors [42] about a significant reduction in functional and motor abilities of athletes with cerebral palsy during a long break in training, which related to lack of selfmovement.

Reina et al. [43] found that the lagging link in the structure of physical preparedness of football players with $\mathrm{CP}$ is speed and strength training, which related with the features of the disease. Differences in jumps between active functional classes (FT5 - FT8) were analyzed and it was determined that only players of class FT8 (less serious lesions) had significantly higher results in all jumping tests than players of lower classes $(p<0.01)$. We supplemented the data obtained by Reina [44] during the classification process about the difference in the level of motor skills between players of sports classes FT5, FT6, FT7 and FT8. FT5 and FT6 players had the worst scores in the tests. Athletes of the FT7 class had limited activity in walking and running on the injured side. Although the athlete usually moves with noticeable limping, it can almost completely disappear while running.

Based on the data obtained during the control and analysis of indicators, we have for the first time developed criteria for assessing the preparedness of football players with $\mathrm{CP}$, taking into account their motor abilities (sports classes). This approach in CP-football is the most correct, because it is justified by the degree of impairment to the musculoskeletal system. This, in turn, in different ways limits the motor abilities of athletes of this nosology. Testing was conducted at the final stage of preparation for international competitions, when players were in the state of greatest training. Quantitative characteristics of the level of physical fitness and functional state can be classified as "regulatory requirements". Their achievement is ensured by the optimal functioning of bodies ' basic systems. They are optimal and reflect the real state of the training process on this level of team development.

\section{Conclusions}

Literary analysis on the problem of research and generalization of training of football players with $\mathrm{CP}$ at the stage of preparation for higher achievements revealed problematic issues. These issues are the lack of comprehensive assessment and the lack of criteria to assess the level of various aspects of preparedness of athletes with special needs. The obtained data of control of physical fitness and functional condition of football players with $\mathrm{CP}$ made it possible to develop criteria for assessing the level of players ' preparedness. This allows coaches to determine the effectiveness of the training period, to obtain information about players ' condition and on this basis to individualize the workload for players and 
adjust the training process. The analysis of the direction of training process is carried out based on the obtained data Also decisions about the correction of the educational and training process of football players with disabilities may be made in various structural formations of the annual macrocycle.

Prospects for further research are the creation of criteria for assessing the technical and tactical readiness of football players with cerebral palsy, taking into account the functional classes of athletes.

\section{Acknowledgements}

Special thanks to the management of the Ukrainian center "Invasport", the coaching staff and doctors of the national CP-football team of Ukraine.

\section{Conflict of interest}

The authors declare no conflict of interest.

\section{References}

1. Koval's'kij P. Problems of physical rehabilitation of disabled children. In: Olimpijs 'kij sport i sport dlia vsikh. Kiev; 2000. P. 605. (In Ukrainian)

2. Ovcharenko SV, Yakovenko AV. Features of football training for athletes with cerebral palsy. Dnipropetrovsk; 2015. (In Ukrainian)

3. Briskin YuA. Organizational foundations of Paralympic sports. Lviv; 2014. (In Ukrainian)

4. Kogut I. State support for disabled sports in Ukraine. Moloda sportivna nauka Ukraini, 2007; 11 (5): 167-172. (In Ukrainian)

5. Ovcharenko SV, Malojvan IaV, Griukova VV, Alf'orov OA. The state of development of the Paralympic movement in Ukraine at the present stage. Naukovo-pedagogichni problemi fizichnoi kul'turi, 2018; 11 (105): 100-103. (In Ukrainian)

6. Center for Physical Culture and Disabled Sports "Invasport". [Internet]. 2020. [updated 2020 May 1; cited 2020 July 8]. Available from: http://invasport.com.ua/

7. National Committee for Sports for the Disabled in Ukraine. [Internet]. 2020. [updated 2020 May 1; cited 2020 July 8]. Available from: https://paralympic.org.ua/ua

8. International Association of Sports and Rehabilitation of People with Cerebral Palsy. [Internet]. 2020. [updated 2020 May 1; cited 2020 July 8]. Available from: https://cpisra.org/

9. International Federation of Cerebral Palsy Football (IFCPF). Classification Rules and Regulations, [Internet]. 2018. [updated 2020 May 1; cited 2020 July 8]. Available from: https://www.ifcpf.com/about-classification

10.Tweedy SM, Vanlandewijck YC. International paralympic committee position stand-background and scientific principles of classification in Paralympic sport. Sports Medicine, 2011; 45: 259-269. https://doi.org/10.1136/bjsm.2009.065060

11. Reina R, Iturricastillo A, Sabido R, Campayo-Piernas M, Yanci J. Vertical and horizontal jump capacity in international cerebral palsy football players. International Journal of Sports Physiology, 2018; 13: 597- 603. https://doi.org/10.1123/ijspp.2017-0321

12.Reina R, Sarabia JM, Caballero C, Yanci J. How does the ball influence the performance of change of direction and sprint tests in para-footballers with brain impairments? Implications for evidence-based classification in CP-Football. PLOS ONE, 2017; 12. https://doi.org/10.1371/journal.pone.0187237

13.Reina R, Sarabia JM, Yanci J, Garcia-Vaquero MP, Campayo-Piernas M. Change of direction ability performance in cerebral palsy football players according to functional profiles. Frontiers in Physiology, 2015; 6: 409. https://doi.org/10.3389/fphys.2015.00409

14.Tweedy SM, Beckman EM, Connick MJ. Paralympic classification: conceptual basis, current methods, and research update. $P M \quad R, 2014 ; 6$ : 11-17. https://doi.org/10.1016/j.pmrj.2014.04.013

15.Sporis G, Jukic I, Milanovic L, Vucetic V. Reliability and factorial validity of agility tests for soccer players. The Journal of Strength and Conditioning Research, 2010; 24: 679-686. https://doi.org/10.1519/JSC.0b013e3181c4d324

16.Sassi RH, Dardouri W, Yahmed MH, Gmada N, Mahfoudhi ME, Gharbi Z. Relative and absolute reliability of a modified agility T-test and its relationship with vertical jump and straight sprint. The Journal of Strength and Conditioning Research, 2009; 23: 1644-1651. https://doi.org/10.1519/JSC.0b013e3181b425d2

17.Miller MG, Herniman JJ, Ricard MD, Cheatham CC, Michael TJ. The effects of a 6-week plyometric training program on agility. Journal of Sports Science and Medicine, 2006; 5: 459-465.

18.International Paralympic Committee (IPC). IPC Athlete Classification Code. [Internet]. 2015. [updated 2020 May 1; cited 2020 July 8]. Available from: https://www.paralympic. org/classification-code

19. Reina R, Iturricastillo A, Castillo D, Urbán T, Yanci J. Activity limitationandmatchloadinpara-footballers withcerebralpalsy: An approach for evidence-based classification. Scandinavian Journal of Medicine, Science and Sports, 2020;30:496-504. https://doi.org/10.1111/sms.13583

20.Bloomfield J, Polman R, O'Donoghue P. Deceleration movements performed during FA premier league soccer matches. Journal of Sports Science and Medicine, 2007; 10: 6-11.

21.Davids K, Lees A, Burwitz L. Understanding and measuring coordination and control in kicking skills in soccer: Implications for talent identification and skill acquisition. Journal of Sports Science, 2000; 18: 703-714. https://doi.org/10.1080/02640410050120087

22.Bangsbo J, Norregaard L, Thorso F. Activity profile of competition soccer. Canadian Journal of Sport Science, 1991; 16: 110- 116 .

23.Ovcharenko S, Kunicia O, Yakovenko A. Individual speed and strength training of Paralympic national team players in the preparatory period. Moloda sportivna nauka Ukraini, 2011; 15 (11): 210-214. (In Ukrainian)

24.Kostiukevich VM, Vrublevs'kij IeP, Vozniuk TV. Theoretical and methodological bases of control in physical education and sports. Vinnytsia LLC "Planer"; 2017. (In Ukrainian)

25. Shamardin VN. Dynamics of model characteristics of physical fitness of a football team of the highest qualification at various stages of the annual macrocycle. Pedagogichni nauki, fizichne vikhovannia ta sport, 2012; 98 (4): 232-234. (In Russian)

26.Reina R, Sarabia JM, Yanci García-Vaquero MP, CampayoPiernas M. Change of direction ability performance in cerebral palsy football players according to functional profiles. Frontiers in Physiology, 2016; 6: 409. https://doi.org/10.3389/fphys.2015.00409 
27.Marfell-Jones M, Olds T, Stewart A, Lindsay Carter LE. ISAK manual, International standards for Anthropometric Assessment. International Society for the Advancement of Kinanthropometry; 2012.

28.Litvinov VN, Kubasov VI, Kabak EL. Methodical guidelines for assessing the actual aerobic ability and physical condition of students. Dnepropetrovsk; 1990. (In Russian)

29.Koc IaM. Physiological foundations of physical (motor) qualities. Sports physiology. Moscow; 1986. (In Russian)

30.Karpman VL. Sports medicine: Moscow; 1987. (In Russian)

31.Tiulen'kov SIu. Methodology for assessing the physical performance of highly qualified football players. Football. Moscow; 1986. (In Russian)

32.Skomorokhov EV. Complex control and methods of improving the special preparedness of highly qualified football players. [PhD thesis]. Moscow; 1980. (In Russian)

33.Ovcharenko SV, Petrov OP, Yakovenko AV. Planning the training process of football players with cerebral palsy for international competitions. Fizichne vikhovannia, sport $i$ zdorov'ia liudini, 2014; 7: 233-238. (In Ukrainian)

34.Zavorotnaia OA. The development of coordination abilities in basketball players 13-14 years old with hearing impairments [PhD thesis]. Dnepropetrovsk; 2008. (In Russian)

35.Pitin MP. Strength training of disabled basketball players [PhD thesis]. Lviv; 2007. (In Ukrainian)

36.Sobko IM. Innovative technologies in the training process of qualified basketball players with hearing impairments $[\mathrm{PhD}$ thesis]. Kyiv; 2014. (In Ukrainian)

37.Perederij AV. Technical training of athletes with the consequences of cerebral palsy, taking into account the peculiarities of motor memory (on the example of athletics) [PhD thesis]. Lviv; 2002. (In Ukrainian)
38.Derkach VM. Management of the training process of Paralympic athletes in the competitive period [ $\mathrm{PhD}$ thesis]. Dnipro; 2017. (In Ukrainian)

39.Pechko GIu. Physical training of highly qualified barriers with hearing impairments at the stage of maximum realization of individual capabilities [ $\mathrm{PhD}$ thesis]. Dnipro; 2018. (In Ukrainian)

40.Ovcharenko SV, Yakovenko AV. Relationships between indicators of physical fitness and game activity of football players with musculoskeletal disorders. Sportivnij visnik Pridniprov'ia, 2013; 1: 126-130. (In Ukrainian)

41.Yanci J, Castillo D, Iturricastillo A, Urban T, Reina R. External match loads of footballers with cerebral palsy: A comparison among sport classes. International Journal of Sport Physiology and Performance, 2019; 13: 590-596. https://doi.org/10.1123/ijspp.2017-0042

42.Lukovs'ka O, Petrechuk L, Miznikov Ie, Ovcharenko S. Functional state of the respiratory system of disabled athletes with the consequences of cerebral palsy. Sportivnij visnik Pridniprov'ia, 2015; 1: 142-146. (In Ukrainian)

43.Reina R, Iturricastillo A, Sabido R, Campayo-Piernas M, Yanci J. Vertical and horizontal jump capacity in international cerebral palsy football players. International Journal of Sport Physiology and Performance, 2018; 13: 597-603. https://doi.org/10.1123/ijspp.2017-0321

44.Reina R, Sarabia JM., Yanci J, García-Vaquero MP, Campayo-Piernas M. Change of direction ability performance in cerebral palsy football players according to functional profiles. Frontiers in Physiology, 2016; 6: 409. https://doi.org/10.3389/fphys.2015.00409

\section{Information about the authors:}

Serhii Ovcharenko; https://orcid.org/0000-0003-4345-4021; Sergey_dnepr2008@ukr.net; PhD of Physical Education and Sport; Docent; Department of Sport Games; Prydniprovsk State Academy of Physical Culture and Sport; Dnipro, Ukraine.

Artem Yakovenko; https://orcid.org/0000-0003-0338-8437; yakovenkoartem2012@gmail.com; PhD of Physical Education and Sport; Department of Sport Games; Prydniprovsk State Academy of Physical Culture and Sport; Dnipro, Ukraine.

Tetiana Sydorchuk (Corresponding author); https://orcid.org/0000-0001-7129-1616, sydorchuk1704@gmail.com; PhD of Physical Education and Sport; Department of Theory and Methods of Physical Education; Prydniprovsk State Academy of Physical Culture and Sport; Dnipro, Ukraine.

Iryna Stepanova; https://orcid.org/0000-0002-5431-8052, siv260180@gmail.com; PhD of Physical Education and Sport; Docent; Department of Theory and Methods of Physical Education; Prydniprovsk State Academy of Physical Culture and Sport; Dnipro, Ukraine.

Oleksandr Pikiner; https://orcid.org/0000-0002-1504-8635; pikadu@i.ua; PhD of Physical Education and Sport; Department of Theory and Methods of Physical Education; Prydniprovsk State Academy of Physical Culture and Sport; Dnipro, Ukraine.

Cite this article as:

Ovcharenko S, Yakovenko A, Sydorchuk T, Stepanova I, Pikiner O. Criteria for assessing the level of physical fitness and physical state of football players with cerebral paralysis, taking into account their sports classes. Pedagogy of Physical Culture and Sports, 2021;25(2):125-131.

https://doi.org/10.15561/26649837.2021.0207

This is an Open Access article distributed under the terms of the Creative Commons Attribution License, which permits unrestricted use, distribution, and reproduction in any medium, provided the original work is properly cited (http://creativecommons.org/licenses/by/4.0/deed.en).

Received: 02.10.2020

Accepted: 04.11.2020; Published: 30.04.2021 